\title{
THE EFFECT OF ORGANIZATIONAL CLIMATE AND COMPENSATION ON EMPLOYEE JOB SATISFACTION IN THE SOCIAL SERVICE OF GORONTALO DISTRICT
}

\author{
Junita Claudia Pahrun ${ }^{1)}$, Hapsawati Amran²), and Amrain Mustafa ${ }^{3)}$ \\ 1,3) Postgraduate Program of STIA Bina Taruna Gorontalo \\ 2) Gorontalo State University \\ E-mail: junitaclaudia@gmail.com
}

\begin{abstract}
The objectives of this study are: 1) to examine the influence of organizational climate on job satisfaction of the employees of the Gorontalo District Social Service; 2) to examine the effect of compensation on job satisfaction of Gorontalo District Social Service staff; 3) to test the effect of organizational climate and compensation simultaneously on job satisfaction of employees of the Gorontalo District Social Service.

This study uses a descriptive research approach and explanatory research methods. Explanatory method is research that proves the existence of cause and effect and a relationship that affects or is influenced by two or more variables under study. Research quantitative research which is based on the philosophy of positivism, is used to examine specific populations or samples, data collection using research instruments, quantitative/statistical data analysis, with the aim of testing predetermined hypotheses. The research was conducted at the Gorontalo District Social Service and was carried out from August to December 2020 with a total sample of 51 people.

Based on the results of data processing, the conclusions are formulated, namely: 1) there is a positive and real influence of organizational climate on employee job satisfaction at the Gorontalo District Social Service, which means that the higher the organizational climate, the higher the employee job satisfaction; 2) there is a positive and real effect of compensation on job satisfaction of employees at the Gorontalo District Social Service, which means that the better the compensation, the higher the job satisfaction of the employees; 3 ) there is a positive and real influence simultaneously between organizational climate and compensation on employee job satisfaction at the Gorontalo District Social Service. This means that the higher the organizational climate and the better the compensation, the higher the employee's job satisfaction.
\end{abstract}

Keywords: job satisfaction, compensation organizational climate

\section{INTRODUCTION}

One of the obligatory tasks that must be carried out by the Gorontalo District Social Service is to continuously improve the data so that the data on the families of social assistance recipients is more valid and synchronized with the data contained in the Data and Information Center of the
Ministry of Social Affairs. The validity and synchronization of this data will ensure the accuracy and suitability of the beneficiaries of the social assistance. Therefore, it is very important to carry out reconciliation and periodically report the results of the distribution of social assistance to the Ministry of Social Affairs so that it can

Submit: Oct. $16^{\text {th }}, 2020$ Accepted: Dec. $5^{\text {th }}, 2020 \quad$ Published: Dec. $17^{\text {th }}, 2020$ Journal of Economics, Business and Administration (JEBA) - E-ISSN: 2746-1688 34 
build synergy and collaboration between the central and regional governments in resolving the obstacles faced by families of social assistance beneficiaries.

To achieve organizational goals, employee job satisfaction is needed. Employee job satisfaction is a strategic element in determining whether an organization is healthy or not. High and sustainable employee job satisfaction is an absolute necessity, especially for the future of the organization. If the organization creates a good work climate, employees will like their work and be able to collaborate well with other colleagues so that they will feel comfortable and satisfied at work.

Employees who get satisfaction at work will be more enthusiastic in completing their duties and job responsibilities. In addition, it is also reflected in the positive attitude of employees towards work and everything they face in the work environment of the Gorontalo District Social Service. Job satisfaction means an employee's attitude towards work related to work situations, cooperation between employees or organizational climate, rewards received at work, and other matters relating to physical and psychological factors or compensation [4].

The results of the data analysis show that the relationship between job satisfaction and compensation includes:

1. Match between salaries and wages paid with the workload performed by employees,

2. Increase in salary according to the minimum needs of employees,

3. Opportunities for salary or wage increases,

4. The opportunity for employees to get a promotion,

5. Promotional activities are based on performance and,

6. Career success is more proportionate when working in social services, with a score of 7 respondents or $73 \%$ said they were satisfied and as many as 3 people or $27 \%$ of respondents said they were dissatisfied.

Based on this description, the problem of employee satisfaction related to organizational climate and compensation is important to conduct a study with the title: "The Effect of Organizational Climate and Compensation on Employee Satisfaction at the Gorontalo District Social Service".

Based on the description on the background, the following research problems were formulated:

1. Does the organizational climate affect the job satisfaction of employees at the Gorontalo District Social Service?

2. Does compensation affect the job satisfaction of employees at the Gorontalo District Social Service?

3. Does the organizational climate and compensation have a simultaneous effect on employee job satisfaction at the Gorontalo District Social Service?

The objectives of this study are as follows:

1. To test the influence of organizational climate on job satisfaction of Gorontalo District Social Service employees,

2. To test the effect of compensation on job satisfaction of Gorontalo District Social Service employees,

3. To test the effect of organizational climate and compensation simultaneously on job satisfaction of employees of the Gorontalo District Social Service.

Public administration is a collaboration carried out by a group of people or institutions in carrying out government tasks to achieve goals effectively and efficiently in order to meet public needs.

Human resource management is the science and art of managing labor relations and roles including planning, organizing, directing and monitoring activities for procurement, development, integration in 
order to pay attention to work relations, health, security and problems in the organization.

Job satisfaction (Y) is an assessment of employees about the extent to which their overall job satisfies needs [7]. Organizational climate is a reflection of the culture that is formed in the organization and describes the quality of the internal environment and is relatively ongoing, experienced by employees; and affect behavior, organizational characteristics [2]. The characteristics or dimensions of organizational climate affect the motivation of organizational members to behave in a certain way. Organizational climate can be described and measured in six dimensions which include structure, standards, responsibility, recognition, support and commitment [9].

Compensation is all income in the form of money, direct or indirect goods received by employees as compensation for services provided by the organization. Referring to this definition, the hypothesis in this study can be formulated as follows:

1. Organizational climate affects employee job satisfaction at the Gorontalo District Social Service,

2. Compensation affects the job satisfaction of employees at the Gorontalo District Social Service. Organizational climate and compensation simultaneously affect employee job satisfaction at the Gorontalo District Social Service.

\section{RESEARCH METHODS}

This research will use a descriptive research approach and explanatory research methods. The research was conducted at the Gorontalo District Social Service and was carried out from August to December 2020. The population was all employees of the Gorontalo District Social Service, totaling 51 people. The sample size in this study was 51 people or all members of the population.
Dependent variable or dependent variable $(\mathrm{Y})$ or job satisfaction, variable $\mathrm{X} 1$ is organizational climate and variable compensation X2. Job satisfaction (Y) is the employee's assessment of the extent to which his overall job satisfies needs which include the work itself, work environment conditions, supervision or relationship with superiors, personality suitability with work, co-workers, rewards, work procedures or regulations and communication.

Organizational climate is a reflection of the culture formed in the organization which describes the quality of the internal environment and is relatively ongoing, experienced by employees; and influencing the behavior, characteristics or nature of the organization, which includes structure, standards, responsibilities, rewards, support, risk commitment (risk), warmth, conflict and identity. Compensation (X2) is all income in the form of money, direct or indirect goods received by employees in return for services provided by the organization against salaries, wages, incentives, allowances, facilities, rewards or rewards and promotions.

Data analysis techniques in research using primary data, namely questionnaires and secondary data is document study. The results of the validity test showed that the valid questionnaire items for the $\mathrm{Y}$ variable were 31 items, 32 items for $\mathrm{X} 1$, organizational climate, and 25 for $\mathrm{X} 2$ for compensation.

The results of the questionnaire reliability test results of job satisfaction (Y) $=0.974$ very high, organizational climate $(\mathrm{X} 1)=0.958$ very high and compensation $(\mathrm{X} 2)=0.958$ very high .

\section{RESEARCH RESULT Testing (X1) against (Y)}

The linear regression test results obtained by the equation $\hat{\mathrm{Y}}=65.976+$ $0.422 \mathrm{X} 1$ and the results of the significance 
test for the direction of the regression coefficient show that the price is $0.000>$ 0.05 , so $\mathrm{H} 0$ is rejected, meaning that the regression equation $\hat{\mathrm{Y}}=65.976+0.422 \mathrm{X} 1$ is very significant. The results of the regression linearity test of $\mathrm{Y}$ on $\mathrm{X} 1$ obtained Ftable $<$ Fcountl value, namely $2.0678<43.939$ and a significance of 0.000 $<0.05$. The results of testing the strength of the influence of $\mathrm{X} 1$ on $\mathrm{Y}$ obtained a correlation coefficient (r) of 0.688 and a coefficient of determination (r2) of 0.473 or $47.30 \%$ in the strong category. The test results show that tcount $=6.629$ while tlist is 2.402 so that the price of tcount $>$ ttable is $6.629>2.402$, then $\mathrm{H} 0$ is rejected, then $\mathrm{H} 1$ is a significant effect of organizational climate on job satisfaction. The result of the partial correlation coefficient test (correlations) was obtained at 0.422 which is positive and the significance value is $0.002<0.05$, it can be concluded that there is a positive and significant influence between compensation on employee job satisfaction without the control variable X2 or kompenasai and the correlations value is 0.422. this falls into the strong relationship category.

\section{Testing (X2) against (Y)}

The linear regression test results obtained by the equation $\hat{Y}=30.447+$ $0.711 \mathrm{X} 2$ and the results of the significance test of the direction of the regression coefficient show that the value of Fcount $>$ Ftable is 35.312> 3,988 and a significant price of $0.000<0.05$ then $\mathrm{H} 0$ is rejected, meaning that the regression equation $\hat{\mathrm{Y}}=$ $30.447+0.711 \mathrm{X} 2$ is significant. The results of testing the influence of $\mathrm{X} 2$ on $\mathrm{Y}$ obtained a correlation coefficient $(r)$ of 0.647 for a correlation coefficient (r) and a coefficient of determination (r2) of 0.419 or $41.90 \%$ with a fairly strong level of influence quality.

The test results show that $t$ table $<$ tcount or 5.942> 2.402 and siginfikan $0.000<0.05$ then $\mathrm{H} 0$ is rejected and $\mathrm{H} 1$ which says there is a significant and positive effect of compensation on job satisfaction is accepted.

The results of the correlation coefficient test (correlations) obtained at 0.306 are positive and the significance value is $0.031<0.05$, it can be concluded that there is a positive and significant effect of compensation on employee job satisfaction without the control variable X1 or organizational climate and the correlations value is 0.306 or $30.60 \%$ belong to the strong influence category.

\section{Simultaneous Influence}

The result of multiple pregression test shows that the multiple regression equation becomes $\hat{Y}=42.092+0.282 \mathrm{X} 1+0.349$ $\mathrm{X} 2$. The results of the regression significance test showed that the significance of multiple regressions, obtained Fcount $>$ Ftable, or 26,219> 4.04 and a significance of $0.000<0.05$ so that the multiple regression equation $\hat{\mathrm{Y}}=$ $42.092+0.282 \mathrm{X} 1+0.349 \mathrm{X} 2$ is significant. The results of testing the strength of the influence of organizational climes and compensation simultaneously obtained the price of Ry1.2 $=0.723$ and the coefficient of determination obtained the price of $\mathrm{R} 2 \mathrm{y} 1.2=0.522$. or $52.20 \%$ is in the category of a strong enough influence.

The results of the multiple regression coefficient test for the price of tcount> ttable, namely $6.629>3.443$, then $\mathrm{HO}$ is rejected, meaning that the correlation coefficient $\mathrm{X} 1$ and $\mathrm{X} 2$ with $\mathrm{Y}$ is very significant. These results indicate that the effect of organizational climate and compensation simultaneously on job satisfaction is positive and significant.

\section{DISCUSSION \\ Effect (X1) on (Y)}

Based on the regression equation, it is obtained that $\hat{Y}=65.976+0.422 X 1$. These results indicate that each increase in the organizational climate score can increase the employee job satisfaction score by 0.422 at a constant $=65.976$. These results 
indicate that each increase in the organizational climate score is also followed by an increase in employee job satisfaction or the higher the organizational climate, the higher the employee job satisfaction.

The results of testing the strength of the influence of organizational climate on employee job satisfaction obtained a coefficient of determination (r2) of 0.422 . The variance that occurs in employee job satisfaction can be explained by organizational climate. These results also indicate that the influence of organizational climate on employee job satisfaction is $47.30 \%$. with a level of quality that is quite strong. Meanwhile, $52.70 \%$ of the variations in employee job satisfaction can be explained by other factors. The strong influence of organizational climate on employee job satisfaction shows that organizational climate is the most important part of creating employee job satisfaction.

The results of this study indicate that as much as $52.70 \%$ of employee job satisfaction is determined by other factors. Work climate and motivation have a positive and significant influence on employee performance, either partially or simultaneously. Thus, employee performance can be improved through improving work climate and motivation [9].

The results of hypothesis testing show that Tcount $>$ Ttable, namely $6.629>2.402$, then $\mathrm{HO}$ is rejected, meaning that the correlation coefficient $\mathrm{X} 1$ and $\mathrm{Y}$ is very significant, so $\mathrm{H} 0$ is rejected, meaning that the correlation coefficient $\mathrm{X} 1$ and $\mathrm{Y}$ is very significant. The test results show that the correlation coefficient (correlations) of 0.422 is positive and the significance (2tailed) value is $0.002<0.01$, it can be concluded that there is a positive and significant influence between compensation on employee job satisfaction without the control variable $\mathrm{X} 1$ or
Organizational climate and the correlations of 0.422 fall into the strong relationship category.

This data illustrates that organizational climate is an important factor in increasing employee job satisfaction. A significant correlation between variable $\mathrm{X} 1$ and variable $\mathrm{Y}$. The results of the analysis of the influence of school organizational climate (X2) on teacher job satisfaction (Y) show that the results of the correlation test between school organizational climate and teacher job satisfaction are Rcount $=0.724$. Organizational climate can affect motivation, achievement and job satisfaction. Work climate is part of the social environment that has an influence on one's job satisfaction [8]. The results of the above research indicate that the organizational climate variable has a significant effect on job satisfaction. This means that the better, the organizational climate in a food institution, the higher the job satisfaction will be. In this regard, to optimize job satisfaction, the organizational climate must always be maintained to be conducive and pleasant.

Organizational climate is a condition that shows an interacting life, giving rise to a feeling of pleasure or displeasure with the field of work. This implies that the interaction has a relationship between superiors and subordinates as well as subordinates and other subordinates. This happens in the interaction process, where there is a communication that is used as a medium to convey messages so that there is a relationship or response from those who receive information.

Several factors can measure organizational climate: Quality of leadership, level of trust, up and down communication, feeling of doing useful work, responsibility, fair reward, reasonable work pressure, opportunity, control, structure, and bureaucracy that makes sense and involvement. employees. There are four factors that determine the 
climate of an organization. The four factors are: organizational structure, technology, external environment and a management process policy [3].

Climate, organization basically can be expressed as an organizational climate that occurs Gorontalo District Social Service is a form of interaction with each other which is collectively involved in an environment and creates good working conditions and atmosphere. Organizational climate is the environmental quality that occurs relatively experienced by employees which affect their attitudes and it is based on mutual interests [6]. The results of this study indicate that a climate in Gorontalo District Social Service will arise through the interaction of members and exchange of feelings among employees. The best organizational climate is an open climate, meaning that an open climate means cooperation and mutual respect between employers and employees and other elements.

The organizational climate in the Gorontalo District Social Service has shown an effect on employee job satisfaction in carrying out tasks. Therefore it is important to pay attention to organizational climate as an illustration for achieving organizational goals. Organizational climate builds a conducive situation for employees to carry out their respective duties in support of organizational performance.

Based on the results of research on the employee job satisfaction variable, it was found that the results were quite good, meaning that employees were quite satisfied with their work. This is inseparable from the various factors that influence organizational climate as stated, employee job satisfaction is influenced by factors [5]:

1. Fair and proper remuneration,

2. The right placement according to expertise,

3. The weight of work,
4. The atmosphere and work environment,

5. Equipment that supports the implementation of work,

6. The attitude of the leader in his leadership; and

7. The nature of work is monotonous or not [5].

The findings of this study indicate that the organizational climate variable has an influence of $47.30 \%$ on employee job satisfaction, while the remaining $52.70 \%$ is influenced by other factors. This means that the better the organizational climate, the higher the employee job satisfaction. Therefore, to optimize employee job satisfaction, the organizational climate must always be conducive. These results indicate that organizational climate is an important factor and must be taken into account in an effort to increase employee job satisfaction.

This finding is that generally leaders, employees and staff want a pleasant climate because it leads to better performance, job satisfaction, and morale. Conversely, if the climate of labor organizations will affect performance. States that a work environment that is less supportive such as the physical environment of work and unsuitable relationships between employees and other employees also causes poor performance [7].

Job satisfaction is a combination of psychological, physical, and environmental conditions. Specifically, that the causes of employee dissatisfaction contained in the organizational climate explain that it is important to maintain a positive organizational climate in an effort to maintain and increase employee job satisfaction [6]. Job satisfaction is the degree to which a person feels positive or negative about various aspects of work, workplace, and relationships with coworkers. The organizational climate will influence the behavior of employees in 
carrying out their duties at the Social Service of Gorontalo District.

The implication of the test results shows that the hypothesis which says there is an influence of organizational climate on employee job satisfaction at the Gorontalo District Social Service can be accepted with a confidence level of $99 \%$. This condition shows that it cannot be denied that the existence of an organizational climate is one of the most decisive aspects for realizing employee job satisfaction in everyday life.

\section{Effect (X2) on (Y)}

The result of testing the simple regression equation shows that $\hat{Y}=30,447$ $+0,711 X 2$. This result was carried out by the static test which turned out to be at the $99 \%$ level of truth so that it means that the regression equation obtained $\hat{\mathrm{Y}}=30,447+$ $0.711 \mathrm{X} 2$ and is very significant. These results indicate that each increase in the compensation score can increase the employee job satisfaction score by 0.711 with a constant of 30.447 . These results indicate that each increase in the compensation score is also followed by an increase in employee job satisfaction or the higher the compensation, the higher the employee's job satisfaction.

The results of testing the closeness or strength of the effect of compensation on employee job satisfaction obtained a coefficient of determination (r2y2) of 0.419 or $41.90 \%$, including the strong enough category. This result means that as much as $41.90 \%$ of the variance that occurs in employee job satisfaction can be explained by the compensation variable. The strength of the effect of compensation on employee job satisfaction is $41.90 \%$ with a fairly strong quality, while $58.10 \%$ of the variations that occur in employee job satisfaction can be explained by other factors or have a relationship with other factors, besides compensation.

The results of the test output value of the correlation coefficient (correlations) of
0.306 are positive and the significance (2tailed) value is $0.031<0.01$, it can be concluded that there is a positive and significant influence between compensation on employee job satisfaction without the control variable $\mathrm{X} 1$ or Organizational climate and correlations of 0.306 or $30.60 \%$ fall into the strong influence category.

The results of hypothesis testing show that the price of Tcount $>$ Ttable is 5.942> 2.402 so that $\mathrm{HO}$ is rejected. The implication of the results of this study shows that the hypothesis which says there is an effect of compensation on employee job satisfaction at the Gorontalo District Social Service can be accepted with a confidence level of $99 \%$. This condition shows that it cannot be denied that the existence of compensation is one of the very determining aspects for realizing employee job satisfaction.

The results of this study indicate that compensation is an important factor in why people work for an organization and not another. Proper compensation will make employees no longer think about anything other than work, in other words that the employee will focus on the job as his main task, proper compensation is also a tribute to the dedication of an employee who has done a good job.

The financial compensation variable (X1) has a significant direct effect on job satisfaction (Y1) with a path coefficient value of 0.561 . The non-financial compensation variable (X2) has a significant direct effect on job satisfaction (Y1) with a path coefficient value of 0.285 . The financial compensation variable (X1) has a significant direct effect on employee performance (Y2) with a path coefficient value of 0.181 . The non-financial compensation variable (X2) has a significant direct effect on employee performance (Y2) with a path coefficient value of 0.614 . The results of this study indicate that compensation has a positive 
and significant effect on job satisfaction. Compensation means that every activity carried out by an employee is a professional activity, which means that there is a reward for services that have been performed by the employee for the organization [1].

Based on the results of this study, the employee job satisfaction variable, found quite good results, meaning that employees feel quite satisfied with their work. This is inseparable from the effect of compensation. Factors that affect employee job satisfaction are work environment, work discipline, salary/honorarium, employee relations with other employees, employee relations with the leader, motivation, influence of leadership leadership, employee attitudes, knowledge of communication. All of these factors directly or indirectly affect job satisfaction.

The results of this study are clear that employee job satisfaction is influenced by leadership, in this study is compensation. The findings of the study show that the compensation variable gives an effect of $41.90 \%$ on employee job satisfaction while the remaining $50.10 \%$ is influenced by other factors. This means that the better the compensation, the higher the level of employee job satisfaction.

Conversely, the worse the compensation received, the lower the level of employee job satisfaction. Therefore, to optimize employee job satisfaction, the compensation system must be able to be managed properly. Compensation is an important factor and must be considered in an effort to increase employee job satisfaction. Employee job satisfaction is influenced by factors: 1) fair and proper remuneration; 2) proper placement according to expertise; 3) lightness of work; 4) work atmosphere and environment; 5) equipment that supports the implementation of work; 6) leadership attitude in leadership; and 7) the nature of work is monotonous or not. Ffinancial compensation has a significant effect on job satisfaction. This can be proven by the value of $t=5,619$ which is greater than 1.96. For the second variable, it is known that financial compensation has a significant effect on work motivation with the value of $t=7.465$, which is greater than the critical level of 1.96 [5].

Compensation is a factor that influences employee job satisfaction, which includes direct financial compensation, indirect financial compensation, non-financial compensation (job), non-financial compensation (work environment). These indicators have been shown by the evaluation of employees at the Gorontalo District Social Service in the quite good category, this condition needs to be maintained and improved again.

\section{Simultaneous Influence}

The result of multiple equation calculation shows that $\hat{Y}=42,092+0,282$ $\mathrm{X} 1+0,349 \mathrm{X} 2$. This equation implies that one unit of employee job satisfaction score will have an influence on the organizational climate of 0.282 and compensation of 0.349 at a constant of 42.092. If the work climate increases by 0.282 and compensation for the increase is 0.349 , the increase in employee job satisfaction is one unit with a constant of 42.092 .

The results of testing the meaning of multiple regression, obtained a price of $\mathrm{F}=81.0857$. This result is in accordance with the testing criteria, namely accept $\mathrm{H} 0$ if Fcount $\geq$ Ftable and reject $\mathrm{H0}$ if Fcount $>$ Ftable. The results of the analysis show that Fcount $>$ Ftable, namely $26.219>4.04$ and significant $0.000<0.05$, so the multiple regression equation is very significant.

The results of testing the closeness of the relationship between organizational climate and compensation using multiple correlation analysis obtained a price of Ry1.2 $=0.723$ and the coefficient of 
determination obtained a price of $\mathrm{R} 2 \mathrm{y} 1.2=$ 0.522 or $52.22 \%$ with a very strong influence quality. The results of this data processing illustrate that as much as $52.22 \%$ or very strong variations that occur in employee job satisfaction can be explained through organizational climate and compensation. The results of this calculation also reflect that the influence of organizational climate and compensation on employee job satisfaction has a strong enough effect, namely $52.20 \%$ while $41.80 \%$ is determined by other factors.

The results of the analysis of the effect of compensation (X1) and school organizational climate (X2) together on teacher job satisfaction $(\mathrm{Y})$ reveal that the results of the study reveal that the compensation variable and the school organization climate variable together have a significant effect on satisfaction. teacher work. Thus, it is believed that compensation and school organizational climate are used as predictors of teacher job satisfaction. The results of the analysis show that the effect of compensation and school organizational climate simultaneously on teacher job satisfaction is $53.9 \%$, while the remaining $46.1 \%$ is influenced by other factors that also affect the job satisfaction of teachers in Madrasah Aliyah, West Bandung district.

The number of factors that influence teacher job satisfaction when related to the results of this study, reveals that approximately $53.9 \%$ is influenced by school compensation and $52.4 \%$ is influenced by the school organizational climate. The compensation and school organizational climate simultaneously affect teacher job satisfaction is $53.9 \%$. That is, increasing teacher job satisfaction cannot be achieved by increasing compensation alone, but must also be increased through a good organizational climate simultaneously [1].

\section{Conclusions}

Based on the results the conclusions are formulated, namely: 1) there is a positive and real influence of organizational climate on employee job satisfaction at the Gorontalo District Social Service, which means that the higher the organizational climate, the higher the employee job satisfaction; 2) there is a positive and real effect of compensation on job satisfaction of employees at the Gorontalo District Social Service, which means that the better the compensation, the higher the job satisfaction of the employees; 3 ) there is a positive and real influence simultaneously between organizational climate and compensation on employee job satisfaction at the Gorontalo District Social Service. This means that the higher the organizational climate and the better the compensation, the higher the employee's job satisfaction.

\section{REFERENCES}

[1] Bintoro, Julia Astriviani, 2013. The Effect of Financial and Non-Financial Compensation on Job Satisfaction and Employee Performance (Study of Employees of PT. Astra International, Tbk-Daihatsu Malang), Journal of Business Administration (JAB), Vol. 1 No. 1, p 141-150. Available at: http: // business administration. studentjournal.ub.ac.id/index.php/jab/ article/view/20. Retrieved 21 September 2020.

[2] Darodat Tubagus Achad, 2015. The Importance of a High and Absolute Strong Work Culture. Bandung. PT Refika Aditama.

[3] Davis, Keith and Newstrom, 2014, Behavior in Organizations, Seventh Edition, Publisher. Erlangga, Jakarta.

[4] Hamali, Arif Yusuf. 2016. Understanding Human Resources. Yogyakarta: CAPS.Hasibuan, 2017. Human Resource Management. Revised Edition. Jakarta: Earth Literacy. 
[5] Hasibuan S.P Malayu. 2017. Human Resource Management. Revised Edition. Jakarta: Earth Literacy.

[6] Hoy, W.K and Miskel, C.G. 2014. Educational Administration: Theory, Research, and Practice. Yogyakarta: Priansa Donni Student Library June. 2017. Personnel Performance Management in Company HR Management. Bandung: CV Pustaka Setia.

[7] Priansa Donni June. 2017. Personnel Performance Management in Company HR Management. Bandung: CV Pustaka Setia.

[8] Robirodia Zain Ikhwani Jihadi, 2016. The Effect of Compensation and School Organizational Climate on Job Satisfaction of Non Civil Servant Madrasah Aliyah in West Bandung Regency. Journal of Educational Administration Vol.XXIII No.1 April 2016. Available at: https://ejournal.upi.edu/index.php/JA PSPs/article/view/5570. Retrieved 21 September 2020.
[9] Shafarila Asri Wahyuni and Endang Supardi, 2017. Organizational climate and work motivation as a reflection of employee performance (Organizational climate and work motivation as determinants of employee's performance). Journal of Office Management Education Vol. 2 No. 2, July 2017, p. 124-136. Availabel online at: http://ejournal.upi.edu/index. php/jpmanper/article/view/00000. Retrieved: September 13, 2020.

[10] Sari Elviera. 2009. Effect of Compensation and Organizational Climate on Job Satisfaction. urnal Administration and Organization Science Journal of Science.

[11] Sudarsono, S. S., Kamase, J., Ella, H., Rachman, A., \& Dunggio, T. (2020). Big data and content marketing on purchase decisions online in Indonesia. IOSR Journal Of Business And Management (IOSR-JBM), 22(2), 42-46. 